\title{
İngilizce Dersi Test Maddelerinde Resim Kullanımının Test ve Madde Psikometrik Özelliklerine Etkisi ${ }^{1}$
}

\author{
Miray ÖZSU \\ MEB, Öğretmen \\ mirayyolacan0000@gmail.com \\ Orcid ID: https://orcid.org/0000-0003-2769-5183

\section{Niyazi CAN} \\ Prof. Dr., Kahramanmaraş Sütçü İmam Üniversitesi, \\ Eğitim Fakültesi, Eğitim Yön. Tef. Plan. Eko. Bilim Dalı \\ niyazican46@gmail.com \\ Orcid ID: https://orcid.org/0000-0003-4373-0719
}

\begin{abstract}
Öz
Sınıf içi değerlendirme ve ulusal sınavlarda sıklıkla kullanılan çoktan seçmeli maddeler, kök ve seçeneklerden oluşmaktadır. $\mathrm{Bu}$ maddelerin kökleri incelendiğinde farklı disiplinler için resim veya grafik gibi farklı ögelerin eklendiği görülmektedir. Özellikle yabancı dil sınavlarındaki çoktan seçmeli maddelerde kökte bulunan resmin madde kökünü ve cevabı açılayıcı amaç için kullanıldığ 1 görülmektedir. Bu çalışmada İngilizce dersi için çoktan seçmeli maddelerde resim kullanım amacının test ve madde psikometrik özelliklerini nasıl değiştirdiği araştırılmıştır. Bu bağlamda, öncelikle liseye geçiş sınavlarında (TEOG) madde kökünde resim olmayan ancak resim eklemeye uygun olan 20 madde seçilmiş, ardından bu maddelere madde kökünü ve cevabı açıklayacak formatta resimler eklenerek 8.sınıf öğrencilerine uygulanmıştır. Elde edilen bulgulara göre madde ve test psikometrik özelliklerini soru kökünde bulunan resmin kullanım amacına göre değişim gösterdiği bulunmuştur.
\end{abstract}

Anahtar Kelimeler: İngilizce Sınavlar, Çoktan Seçmeli Maddeler, Test ve Madde Psikometrik Özelliği, Görselin Etkisi.

\footnotetext{
${ }^{1}$ Makale Geliş/Kabul Tarihi: 29.02.2020 / 18.04.2020

Künye Bilgisi: Özsu, M. ve Can, N. (2020). Ingilizce Dersi Test Maddelerinde Resim Kullanımınin Test ve Madde Psikometrik Özelliklerine Etkisi. Kahramanmaraş Sütçü Imam Üniversitesi Sosyal Bilimler Dergisi, 17 (1), 85-103. DOI: 10.33437/ksusbd.693800
} 


\title{
The Effect of the Using Visuals in Test Items of English Lessons on Test and Item Psychometric Properties
}

\begin{abstract}
Multiple choice items, consisting of a stem and options, are frequently used in classroom assessment and national exams. When the items are analyzed, it is seen that pictures or graphics are added to the stem of the items for different disciplines. Multiple choice items used in foreign language exams, it is seen that the picture in the stem is used for the purpose of explaining the stem and directing to the answer. In this study, it was investigated how the purpose of using pictures in multiple choice items for English lesson changed the test and item psychometric properties. In this context, first, 20 items that do not have a picture at the stem, suitable for adding pictures, were selected from the high school exams (TEOG). Then they were added pictures in a format that would explain the stem and direct to the answer. Picture added questions and their original formats are applied as an exam to 8th grade students. According to the findings, the item and test psychometric properties were found to vary according to the intended use of the picture at the question stem.
\end{abstract}

Keywords: English Exams, Multiple Choice Items, Test and Item Psychometric Properties, Effect of Visual.

\section{GİRIŞ}

Türkiye'de Millî Eğitim Bakanlığına (MEB) göre temel eğitimin amac1, "Her Türk çocuğunun iyi birer yurttaş olabilmesi için, gerekli temel bilgi, beceri, davranış ve alışkanlık kazanmasını, millî ahlak anlayışına uygun olarak yetişmesini, ilgi, yeti ve yetenekleri doğrultusunda hayata ve bir üst öğrenime hazırlanmasını sağlamaktır” (MEB, 2011). Özellikle öğrencilerin akademik bilgi ve becerilerini ölçmek için gerek sınıf içi değerlendirmeler gerekse kademeler arası geçişlerde ulusal sınavlar uygulanmaktadır. Yapılan bu sınavların formatları ve isimleri yıllar içinde değişiklik gösterse de amacı ve kullanılan soru türü aynı kalmıştır. Örneğin, ilköğretimden ortaöğretime geçişte yapılan bu sınavlar, 1997'den 2008 yılına kadar sadece sekizinci sınıflara yönelik olarak uygulanmış ve Ortaöğretim Kurumlarına Öğrenci Seçme Sınav1 (OKS) olarak adlandırılmıştır (MEB, 2015). 2008 yılından itibaren bu sınav, Seviye Belirleme Sınavı (SBS) olarak altı, yedi ve sekizinci sınıflara uygulanmıştır (MEB, 2015).

2013-2017 yılları arasında sınav, Temel Eğitimden Ortaöğretime Geçiş (TEOG) adı altında uygulanmaya başlamıştır. Altı temel ders (Türkçe, 
Matematik, Fen Bilimleri, İnkılap Tarihi ve Atatürkçülük, Din Kültürü ve Ahlak Bilgisi, İngilizce) için 8. sınıfta öğretmenler tarafından dönemsel olarak yapılan sınavlardan biri ortak olarak Millî Eğitim Bakanlığı tarafından gerçekleştirilmiştir (MEB, 2015). 2013-2017 yılları arasındaki eğitim-öğretim dönemlerinde TEOG dönemde bir, yılda iki kez belirli tarihlerde uygulanmış ve bu tarihlerden üç hafta sonra mazeret sınavı yapılmıştır. Sorular, sınavların yapılacağ 1 tarihe kadar okulda öğretilen ilgili derslerin öğretim programlardan belirlenen kazanımlar esas alınarak öğrencinin eleştirel düşünme, analiz yapma, problem çözme, sonuç çıarma, yorumlama ve benzeri becerilerini ölçecek nitelikte hazırlanmıştır (MEB, 2016). Bu uygulama ile öğrenci performansının, sonuç değil süreç odaklı olarak değerlendirilmesi, öğretim programının bütün ülkede aynı zamanda uygulanması ve program kazanımlarının objektif bir sınav ya da yazılı vasıtasıyla ölçülmesi ve değerlendirilmesi amaçlanmıştır (MEB, 2016). Ayrıca öğrencilerin sınav heyecanı faktörünü minimum düzeye indirmek için sınav, her öğrencinin kendi okulunda gireceği şekilde planlanmıştır. Her biri 20 sorudan oluşan altı temel dersten yapılan sınav, iki günde toplam 6 oturum olarak uygulanmıştır. Her sınava ortalama 1.150.000 öğrencinin girdiği TEOG sınavının sonuncusu 2017 Nisan ayında yapılmışır (MEB, 2017). 2013 Kasım itibariyle her yıl mazeret sınavları dahil dört sınav uygulanmış ve 2017 Nisan dahil olmak üzere toplam 16 sınav yapılmıştır.

2017- 2018 Eğitim- Öğretim Yılı itibariyle sınav, Liselere Geçiş Sınavı (LGS) adı altında uygulanmaya başlanmış ve sınava başvuru öğrencinin isteğine bağlı olarak yapılmıştır. LGS önceki sınav gibi altı temel dersten ancak yılda bir kez, tek gün ve iki oturum olarak eğitim- ögretim yılı sonunda belirlenen merkezlerde uygulanmaya başlanmıştır (MEB, 2017). Seçme ve yerleştirme amacıyla yapılan ortaokuldan liseye geçişte uygulanan bütün sinavlarda, ölçme ve değerlendirme araçlarından çoktan seçmeli testler kullanılmıştır.

\section{Çoktan Seçmeli Testler}

Ölçme araçlarından biri olan çoktan seçmeli testler, testi cevaplayanlar için yanıtlarını belirli sayıdaki seçenekler arasından seçerek vermesini gerektiren maddelerden oluşan ölçme araçlarıdır (Turgut, 1987). Madde, testini puanlanabilen en küçük birimidir. Bir madde, kök ve seçeneklerden oluşur. Seçeneklerde cevaplayanların seçebileceği olası yanıtlar vardır. Seçenekler iki kısma ayrılır; doğru yanıt ve çeldiriciler. Madde köküne doğru yanıtı veren seçeneğe doğru cevap, doğru yanıtı vermeyen seçeneklere ise çeldiriciler denir.

Eğitimin her basamağında kullanılan çoktan seçmeli testlerin kullanımının avantajları ve dezavantajları literatürde oldukça değinilmiştir. Özellikle açık uçlu sorular ile karşılaştırıldığında çoktan seçmeli testlerin en büyük avantajlarından biri, belirlenen sınav süresinde sayıca daha fazla madde kullanımı sağlamasıdır. 
$\mathrm{Bu}$ durum sınavın hem güvenirliğini hem de kapsam geçerliliğini artırabilir. Ayrıca sınav sonuçları değerlendirilirken, çoktan seçmeli testler açık uçlu sorulara göre daha objektif ve nesneldir. Ancak çoktan seçmeli testler, zayıf yönlerinden biri, başarının şansa bağlı olabilme ihtimalidir. Ölçülen davranışa sahip olmayan bireyin şans faktörü ile doğru seçeneği işaretlemesi, şans başarısı olarak nitelendirilir. Ayrıca çoktan seçmeli sorularda çeldiricileri hazırlama süreci oldukça zaman alıcı ve uğraştırıcıdır (Atılgan vd., 2007: 235-238). Çoktan seçmeli testlerin avantajlarından biri psikometrik özelliklerinin incelenmesidir.

\section{Psikometrik Özellikler}

Küçük gruplarda uygulanan çoktan seçmeli testlerin psikometrik değerleri klasik test toerisi (KTT) kullanılarak hesaplanır. Klasik test kuramı gerçek puanı gözlenen puandan kestirmeye çalışan kuramlardan biridir. Klasik test kuramına gerçek puan modeli de denilmektedir (Doğan ve Tezbaşaran, 2003). Kuramın varsayımı, bir bireyin özellikleri sabittir ve gözlenen puanlardaki değişim, yorgunluk veya şans gibi çeşitli faktörlerin sonucu olan random hatalardan kaynaklanır (Crocer ve Algina, 1986). Klasik test kuramında test ve madde psikometrik özelliklerinin hareket noktası madde güçlük düzeyi (p) ve madde ayırıcılı̆̆ıdır (r). Bu istatistikler yardımıyla teste ait özellikler kestirilebilir (Osterlid, 1989). Testin psikometrik değerleri genellikle test güvenirliği, madde güçlük indeksi ve madde ayırt edicilik indeksi olarak sinıflandırılır. Güvenirlik, genel tanımıyla ölçme sonuçlarının tesadüfi hatalardan arınık olma derecesi olarak ifade edilmektedir (Turgut ve Baykul, 2015). Bir ölçme aracının güvenilirliğini arttırmak, madde sayısını arttırmak, maddeleri açık anlaşılır ve net ifadelerle yazmak, öğrencilerin sınava olan motivasyonunu arttırmak, sınav süresinin az ya da çok fazla olmayacak şekilde ayarlamak, tesadüfi hata kaynaklarını olabildiğince azaltmakla mümkün olmaktadır (Atılgan vd., 2007). Testte yer alan maddelerin testin tamamı ile uyumunu güvenirlik katsayıs1 göstermektedir. Güvenirlik katsayısı 0 ile 1 arasında değerler almaktadır. Güvenirlik katsayısının 1'e yakın bir değer alması testin maddeleri arasındaki iç tutarlılığın yüksek olduğu ve testin güvenilir sonuçlar ürettiği şeklinde yorumlanmaktadır (Baykul, 2000). Bir ölçme aracının hatasız ölçebilmesi güvenirliğini, ölçülen özelliği başka özellik karışmaksızın ölçebilmesi de geçerliğini göstermektedir.

Bir maddenin güçlüğü, o maddeye doğru cevap verenlerin sayısının testi alanların sayısına oranıdır. Madde güçlük katsayısı 0 ile 1 arasında değerler alır (Turgut ve Baykul, 2015). Bire yaklaştıkça madde kolaylaşır, sıfıra yaklaştıkça zorlaşır. (Atılgan vd., 2007). Madde güçlük katsayısı hem bir ortalama hem bir yüzde hem de bir olasılık belirtir. Madde güçlügün orta değeri 0.50 'dir. Bu değer her maddenin, orta güçlükte (zorlukta) olduğunu gösterir ve madde güçlük değeri 
sıfira yaklaştıkça (bilmeyen sayısı arttıkça) madde zorlaşır, madde güçlük değeri bire yaklaştıkça (bilen sayısı arttıkça) madde kolaylaşır.

Madde ayırt edicilik gücü, maddenin ölçülen davranışa sahip olanla olmayanı ne ölçüde ayırdığını göstermektedir. Bir maddenin, bilen ile bilmeyeni ayırabilmesinin derecesidir (Turgut ve Baykul, 2015). Maddenin güvenirliğinin bir ölçüsünü veren madde ayırt ediciliği, bir maddenin en önemli istatistiğidir. (Güler, 2015: 58). Bu sebeple bir maddenin teste alınıp alınmamasına karar verilirken öncelikle madde ayırt ediciliğinin yüksek olup olmadığına bakılır. (Güler, 2015: 58). Madde ayırt ediciliği maddenin ölçmek istenilen davranışı ölçüp ölçemediği ile ilgili olduğu için bu katsayıya madde geçerliği de denmektedir. Madde ayırt edicilik gücü bir korelasyon katsayısıdır. Diğer korelasyon katsayıları gibi (-1) ile (+1) aralığında değerler alır. Bu katsayının (+) işaretli değerleri, maddenin ölçtüğü niteliğin testin bütününde ölçülen nitelikle uyumlu olduğunu; (-) işaret değerleri, maddenin ölçtüğü değişkenin testin bütününde ölçülen nitelikle ters yönde ilişki içinde bulunan bir niteliği ölçtüğünü; 0 ve 0 civarındaki değerleri de maddenin ölçtüğü niteliğin testin bütününde ölçülen nitelik arasında ilişki bulunmadığını belirtir. Test geliştirmelerde maddelerin, testin bütünüyle ölçülen niteliklerle uyumlu olması istenir; bu nedenle ayırt edicilik gücü katsayısı (-) işaretli olanlar ve 0 ve 0 civarındaki olan maddeler teste dahil edilmez (Turgut ve Baykul, 2015: 225).

\section{Çoktan Seçmeli Madde Yazımı ve Resim Kullanımı}

Eğitim- öğretim sürecinde kullanılan çoktan seçmeli testler, öğrencilerin bilgi düzeylerini, bilişsel becerilerini öğrenme ve ilerlemelerini belirlemede ve değerlendirmede önemli bir rol oynar. Farklı ölçme ve değerlendirme yöntemleri kullanılsa da çoktan seçmeli soruları içeren testler, yüksek güvenilirliği, geçerliği ve kullanışlılığı sebebiyle yaygın olarak kullanılmaktadır (Haladyna, Downing ve Rodriguez, 2002; McCoubrie, 2004). Ancak soru kökü ve seçeneklerden oluşan çoktan seçmeli sorular oluşturulurken istenilen hedefleri/kazanımları ölçmek, uygun sayıda seçenekleri oluşturmak oldukça ayrıntılı bir süreçtir (Collins, 2006; Haladyna vd., 2002). Çoktan seçmeli maddeler oluşturulurken öncelikle madde yazım ilkeleri göz önünde bulundurulur.

Maddeler yazılırken kazanımların belirlenmesi, belirtke tablosunun oluşturulması, maddenin hedef kitlesinin özellikleri gibi birçok aşamadan geçmektedir ve farklı türde çoktan seçmeli testler oluşturulmaktadır. Önceki çalışmalarda çoktan seçmeli soru yazımında dikkat edilmesi gereken ilkeler üzerinde durulmuştur. Haladyna vd. (2002), çalışmalarında soru yazım ilkelerini: İçerik oluşturma, formatı oluşturma ve seçenekleri yazma alt başlıklarında toplam 31 adet ilke ile belirmişlerdir. İlkeler incelendiğinde, maddedeki okuma miktarının azaltılması (13. ilke), laf kalabalığının yapılmaması (16. ilke) ve doğru 
cevaba yönlendiren ipuçlarından kaçınılması (28. Madde) maddelerinin bu çalışma ile ilgili olduğu görülmüştür. Bu bağlamda ulusal sınavlardaki çoktan seçmeli maddeler incelendiğinde soru köklerine resim, grafik, tablo gibi farklı ögelerin eklendiği görülmektedir. Ayrıca yabancı dil sınavlarındaki çoktan seçmeli maddelerde kökte bulunan resmin madde kökünü veya cevabı açıklayıcı amaç için kullanıldığ 1 görülmektedir. Önceki çalışmalara bakıldığında resim kullanımı ile ilgili çalışmalar yapıldığı görülmektedir.

Yapılan çalışmalara bakıldığında, çoktan seçmeli sorularda resim kullanımının etkisi genellikle tıp- anatomi, aritmetik ve fen bilimleri alanlarında olduğu tespit edilmiştir. Resim kullanımı genellikle psikometrik özellikler, soruları cevaplama süresi ve başarılı- başarısız öğrenci üzerindeki etkisi açısından incelenmiştir. Bu alanda ulaşılan ilk çalışmayı Hunt (1978), tıp alanında çoktan seçmeli sınavlarda görsel kullanımının sınav başarısına etkisini ölçmek amacıyla yapmıştır. Çalışma sonucunca görsel eklenen soruların madde güçlügü azalmış ancak madde ayırt ediciliklerinde istatistiksel olarak anlamlı bir fark görülmemiştir. Olleranshaw vd. (1997), yaptıkları çalışmada maddelere resim eklemenin etkisinin ön bilgi/hazırbulunuşluk düzeyine göre değişkenlik gösterdiği ve konu hakkında bilgisi olmayana daha fazla katkı sağladığı sonucuna ulaşmışlardır. Wasylenky ve Tapajna (2001) ise parça ile ilişkili olan ya da olmayan görselin hatırlamaya olan etkisini ölçmüşler ve parçayla alakalı yani tutarlı görsellerin hatırlamayı olumlu yönde etkilediği, tutarsız görselin olumsuz yönde etkilediği sonucuna ulaşmışlardır. Berends ve Lieshout (2009), aritmetik problem çözümünde resmin etkisini incelemişlerdir. Çalışma resim eklemenin öğrenciyi meşgul ederek soru çözüm süresini uzattığ 1 , bilginin resimle tekrar edilerek faydasız bir etkisinin olduğu sonucuna ulaşmışlardır. Bu çalışmanın sonucu Haladyna vd. (2002), 16. ilkesi ile tutarlılık göstermektedir. Notebaert (2017), anatomi sınavı üzerinde yaptığı çalışmada resim eklemenin madde ayırt ediciliği istatistiksel olarak anlamlı bir şekilde değiştirmemiştir. Özcan vd. (2014), Türkçe dersi sınav soruları üzerinde yaptıkları çalışmalarında, metin sorularında resimlerden etkili bir şekilde yararlanılmadığı ayrıca kullanılan görsellerin istenen amaca hizmet etmediği sonucuna ulaşmışlardır. Vorstenbosch vd. (2013), anatomi sınavı sorularında resim kullanımının test başarısına, madde güçlügü ve madde ayırt ediciliği üzerindeki etkisini incelemişlerdir. Çalışmada, resmin test başarısını, madde güçlüğü ve madde ayırt ediciliği anlamlı olarak etkilemediği sonuca ulaşılmıştır. Önceki araştırmalar incelendiğinde, çoktan seçmeli sorularda resim kullanımı test başarısı ve psikometrik özellikler açısından genel olarak genel olarak olumlu etkilere sahip olmadığı görülmektedir.

\section{Çalışmanın Önemi ve Araştırma Sorusu}

Konu ile ilgili yapılan önceki çalışmalarda maddeye eklenen resmin test başarısı, testin yapılma süresi ve psikometrik özellikleri üzerindeki etkisini 
incelemiştir. Önceki çalışmalarda madde kökünü açıklayan resimlerin etkileri incelenmiştir. Ulaşılan çalışmalarda yabancı dil dersi ya da İngilizce dersi sorularında resim kullanımının etkisi araştırılmamıştır. Bu çalışmada madde kökünü açıklayan resim kullanımının etkisi ve cevaba yönlendiren resim kullanımının etkisi araştırılmıştır. Haladyna vd. (2002), doğru cevaba yönlendiren ipuçları vermekten kaçınılmalı ilkesi (28. ilke) resim kullanımı açısından incelenmiştir. Bu çalışmanın amacı, İngilizce dersi test maddelerinde resim kullanım amacının test ve madde istatistiğini nasıl değiştirdiğini araştırmaktır. Bu bağlamda aşağıdaki sorulara cevap aranacaktır:

1. Madde köküne eklenen ve madde kökünü açıklayan resim, test ve madde psikometrik özelliklerini nasıl değiştirir?

2. Madde köküne eklenen ve cevaba yönelten resim, test ve madde psikometrik özelliklerini nasıl değiştirir?

\section{YÖNTEM}

Bu bölümde çalışmanın evren ve örneklemi, veri toplama araçları ve verilerin analizi yer almaktadır.

\section{Çalışmanın Evren ve Örneklemi}

Çalışmanın örneklemini 2017-2018 eğitim-öğretim yılında Kahramanmaraş'ta 8. sınıf düzeyinde eğitim gören 279 öğrenci oluşturmaktadır. Tablo 1'de görüldüğü gibi kullanılan iki veri toplama aracı için 279 öğrencinin 139'na "A" kitapçığını, 140'na ise "B" kitapçı̆̆ı uygulanmıştır. Kitapçıklar rastgele şekilde dağıtılmıştır. Çalışmada 124 kız 155 erkek öğrenci bulunmaktadır.

Tablo 1. Çalışmanın Örneklemi.

\begin{tabular}{lll}
\hline & Katılımcı Özellikleri & Katılımcı Sayısı \\
\hline \multirow{2}{*}{ Cinsiyeti } & Kız & 124 \\
& Erkek & 155 \\
& “A” Kitapçı̆̆ Dağıtılan & 139 \\
Kullanılan Kitapçık Türü & "B” Kitapçığı Dağıtılan & 140 \\
& & \\
\hline
\end{tabular}




\section{Veri Toplama Araçları}

Çalışmanın veri toplama aracını 2013-2017 yılları arasında 8. sınıf öğrencilerinin liseye geçişleri için yapılan 16 TEOG sınavında bulunan toplam 320 İngilizce dersi sorusu arasından seçilmiş 20 madde oluşturmaktadır. 320 maddeden, madde köküne resim eklenebilecek 33 ve cevaba yönelten resim eklenebilecek 28 madde seçilmiştir. Seçilen maddelere resimler eklendikten sonra her grup için 10'ar soru belirlenmiştir. Resimler, TEOG sınavında kullanılan görsellerin de siyah-beyaz olmasından dolayı aynı formda kitapçıkların baskısı yapılmış ve renksiz olmasının resmin anlaşılırlığını bozup bozmadığına dikkat edilmiştir. Oluşturulan testteki yazı karakteri ve punto büyüklüğü sınavdaki gibidir.

Veri toplama araçlarında, "A" kitapçığının çift numaralı maddelerine $(2,4,6$, $8,10,12,14,16,18,20)$ resim madde köküne eklenirken, aynı maddeler "B" kitapçığında orijinal haliyle bulunmaktadır. "B" kitapçığının tek numaralı maddelerine $(1,3,5,7,9,11,13,15,17,19)$ cevaba yönelten resim eklenirken, "A" kitapçı̆̆ında ise aynı maddeler resimsiz yani sınavda kullanılan orijinal halleriyle bulunmaktadır.

Türkiye'de liselere geçiş sınavında İngilizce çoktan seçmeli test maddeleri incelendiğinde resimlerden sıklıkla faydalanıldığ resimlerin üç farklı amaçla kullanıldığı belirlenmiştir; madde kökünü anlaşılır hale getirmek, doğru seçeneğe yönlendirmek ve seçenekleri sadece resimden oluşturmak. Kullanılan görsellerin ilk iki amacını örnekleyen ve liselere geçiş sınavlarından alınan maddeler Tablo 2'de verilmiştir. 
Tablo 2. TEOG Sınavındaki Resimli Soru Örnekleri.

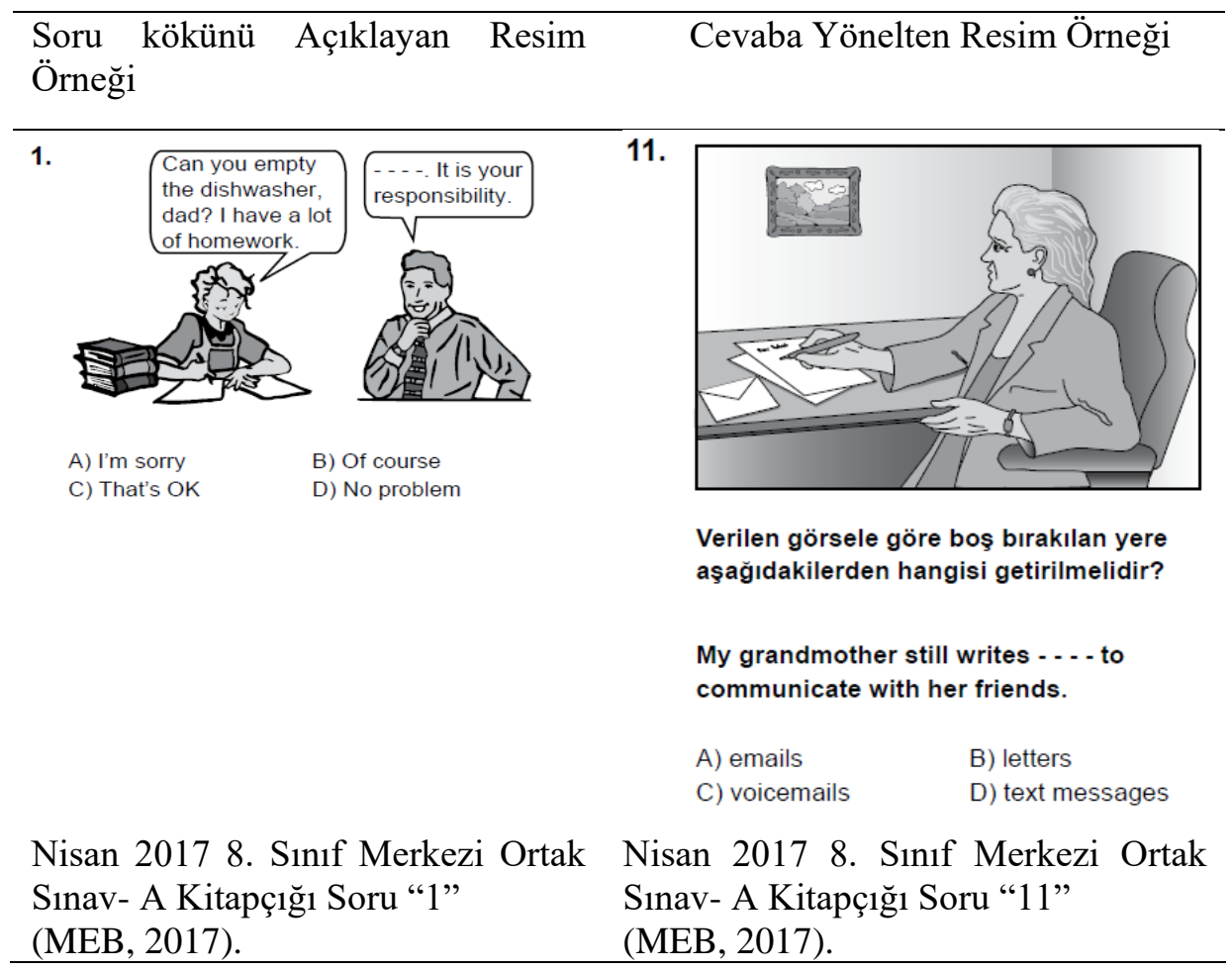

Çalışmanın veri toplama aracında bulunan köküne resim eklenen maddeler ve bu maddelerin orijinalleri; cevaba yönelten resim eklenen maddeler ve bu maddelerin orijinalleri örnekler Tablo 3'te ve Tablo 4'te verilmiştir. 
Tablo 3. "A" Kitapçı̆̆ında Orijinal Halde Bulunan Madde ve "B” Kitapçığında Cevaba Yönelten Resim Eklenen Madde Örneği.

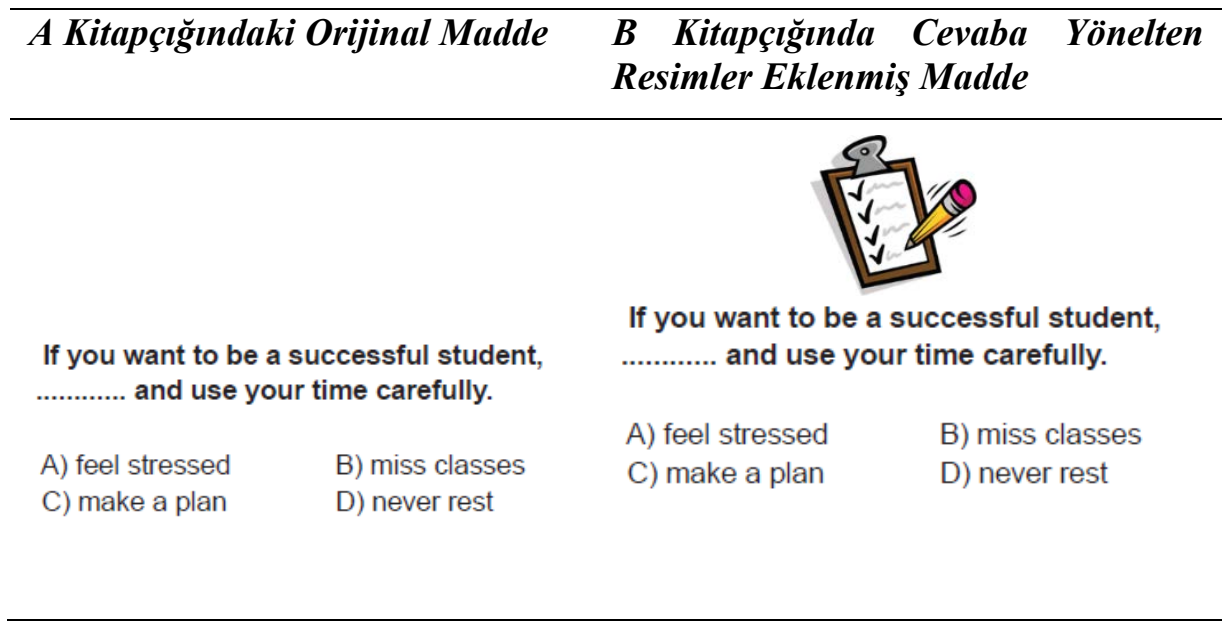

Tablo 4. "B" Kitapçı̆̆ında Orijinal Halde Bulunan Madde ve "A" Kitapçı̆̆ında Soru Köküne Resim Eklenen Madde Örneği.

\section{“B” Kitapçı̆̆ındaki Orijinal Madde “A” Kitapçı̆̆ında Köküne Resim Eklenen Madde}

Ethan : l've decided to be a vet.

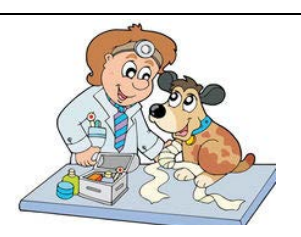

Dean : . . . You are afraid of animals.

Ethan : I've decided to be a vet.
A) I hope so
B) That's weird
C) I agree
D) That's true

\begin{abstract}
A) I hope so
B) That's weird

C) I agree

D) That's true
\end{abstract}

Dean :-...

You are afraid of animals.

Hazırlanan veri toplama araçları Kahramanmaraş ili Onikişubat ilçesinde bulunan 3 ortaokulda, ortalama 25 öğrencinin bulunduğu 11 farklı sınıfta uygulanmıştır. Uygulama esnasında öğrencilerin ders dokümanlarından faydalanmamalarına ve dersliklerde İngilizce dersine ait poster, afiş gibi materyallerin bulunmamasına özen gösterilmiştir. TEOG sınavında 20 sorudan 
oluşan her ders sınavı için öğrencilere 40 dakika süre verildiği için bu çalışmada da 20 soru için 40 dakika süre verilmiştir. Öğrencilere hazırlanan kitapçık ile kodlamalarını yapacakları optik form dağıtılmıştır.

\section{Verilerin Analizi}

İngilizce dersinde çoktan seçmeli maddelerde resim kullanımının test ve madde istatistiğini nasıl etkilediğinin araştırıldığı bu çalışmada karşılaştırma türü ilişkisel tarama modeli kullanılmıştır. Tarama modellerinden biri olan karşılaştırma türü ilişkisel tarama modeli iki veya daha fazla değişkenin değişim derecesini belirlemek amacıyla kullanılır. Bu tarama modelinde ilişki belirlemede bağımsız değişkene göre gruplar oluşturulduktan sonra bağımlı değişkende farklılık olup olmadı gözlemlenir (Karasar, 2012: 79-87). Bu çalı̧̧mada, madde köküne eklenen resim ve cevaba yönelten resim olmak üzere iki bağımsız değişken vardır. $\mathrm{Bu}$ değişkenlerin, bağımlı değişken olan test ve madde istatistiğine etkisini ölçmek için iki ayrı kitapçık oluşturularak her iki değişkenin etkisi ve yönü araştırılmıştır. Kullanılan maddeler Millî Eğitim Bakanlığ 1 tarafından yapılmış sınavlardan alındığı için geçerlik kontrolü yapılmamıştır.

Maddeye eklenen resimlerin madde güçlük ve madde ayırt edicilik değerlerine etkisini belirlemek için 10'ar madde çiftinin (resimsiz formatları ile resim eklenen formatları) belirtilen değerleri hesaplanmıştır. Ardından madde çifti sayıs1 10 olduğu için parametrik olmayan testlerden Wilcoxon İlişki Testi yapılmıştır.

Testin güvenirliğini hesaplamak için 10'ar maddenin orijinal (resimsiz) formatının ve resimli formatının Cronbach Alpha güvenirlik katsayıları hesaplanmıştır. Cronbach Alpha güvenirlik katsayısı sorular arasında uyumu gösterdiği için iç tutarlılığı veren bir değerdir (Büyüköztürk, 2016: 183).

Madde güçlüğü, madde ayırt ediciliği ve testin güvenirliği psikometrik özellikleri hesaplamak için önemli kriterlerdir. Bulgular ve sonuçlar bölümünde her bir maddenin ve testin, madde güçlügü, madde ayırt ediciliği ve her iki kitapçığın test güvenirliği değerlerine yer verilmiştir.

\section{BULGULAR}

Bu bölümde madde güçlüğü, madde ayırt ediciliği ve testin güvenirliği sonuçları sırasıyla verilmiştir. 


\section{Madde Güçlüğü ve Madde Ayırt Ediciliği}

Madde köküne resim eklenen format ile orijinal (resimsiz) madde formattan oluşan 10 madde çifti için madde güçlükleri ve madde ayırt ediciliklerinin farkının değişimini test etmek için, parametrik olmayan testlerden Wilcoxon İlişkili Testi yapılmıştır. Test sonucunda madde güçlük değerleri farklılıklarının istatistiksel olarak anlamlı olmadığ 1 bulunmuştur $(\mathrm{z}=-0,92, \mathrm{p}=0,357)$. Madde ayırt edicilik değerleri farklılıkların ise istatistiksel olarak anlamlı olduğu bulunmuştur $(\mathrm{z}=2,40, \mathrm{p}<0,05)$. Madde kökünde resim eklendiğinde madde ayırt edicilik değerlerinin (medyan değerinin) orijinal madde formatındaki maddelere göre daha yüksek oldukları görülmüştür $\left(\right.$ Medyan $_{\text {orijinal }}=0,49 ;$ Medyan $\left._{\text {resim }}=0,60\right)$. Tablo 5'te her bir maddenin iki formattaki madde güçlük ve madde ayırt edicilik değerleri verilmiştir.

Tablo 5. Orijinal Madde ile Köküne Resim Eklenen Madde Güçlük ve Madde Ayırt Edicilik Değerleri.

\begin{tabular}{|c|c|c|c|c|}
\hline \multirow[b]{2}{*}{$\begin{array}{l}\text { Madde Çifti } \\
\text { (Madde Nu.) }\end{array}$} & \multicolumn{2}{|c|}{$\begin{array}{l}\text { Orijinal (Resimsiz) } \\
\text { Maddeler }\end{array}$} & \multicolumn{2}{|c|}{$\begin{array}{c}\text { Köküne Resim Eklenen } \\
\text { Maddeler }\end{array}$} \\
\hline & $\begin{array}{l}\text { Madde } \\
\text { Güçlük } \\
\text { Indeksi }\end{array}$ & $\begin{array}{l}\text { Madde } \\
\text { Ayırt Edicilik } \\
\text { Indeksi }\end{array}$ & $\begin{array}{l}\text { Madde } \\
\text { Güçlük } \\
\text { Indeksi }\end{array}$ & $\begin{array}{l}\text { Madde Aytrt } \\
\text { Edicilik } \\
\text { Indeksi }\end{array}$ \\
\hline $1(2)$ & 0,86 & 0,50 & 0,84 & 0,61 \\
\hline $2(4)$ & 0,25 & 0,35 & 0,32 & 0,38 \\
\hline $3(6)$ & 0,78 & 0,49 & 0,74 & 0,62 \\
\hline $4(8)$ & 0,73 & 0,45 & 0,64 & 0,59 \\
\hline $5(10)$ & 0,51 & 0,37 & 0,61 & 0,47 \\
\hline $6(12)$ & 0,45 & 0,48 & 0,66 & 0,49 \\
\hline 7 (14) & 0,57 & 0,52 & 0,61 & 0,62 \\
\hline $8(16)$ & 0,78 & 0,51 & 0,71 & 0,66 \\
\hline 9 (18) & 0,54 & 0,63 & 0,61 & 0,62 \\
\hline $10(20)$ & 0,58 & 0,53 & 0,61 & 0,52 \\
\hline
\end{tabular}

Cevaba yönelten resim eklenen madde formatı ile orijinal (resimsiz) madde formatından oluşan 10 madde çifti için madde güçlükleri ve madde ayırt ediciliklerinin farkının değişimini test etmek için parametrik olmayan testlerden Wilcoxon İlişkili Testi yapılmıştır. Testin sonucunda madde güçlük değerleri farklılıklarının istatistiksel olarak anlamlı olduğu görülürken $(z=-2,56, p<0,05)$, madde ayırt edicilik değerleri farklılıklarının istatistiksel olarak anlamlı olmadığ 1 bulunmuştur $(\mathrm{z}=-1,53, \mathrm{p}=0,125)$. Resim olan maddelerin madde güçlük değerlerinin (medyan değerinin) orijinal madde formatındaki maddelere göre daha büyük oldukları görülmüştür $\left(\right.$ Medyan $_{\text {orijinal }}=0,67$ ve Medyan $\left._{\text {resim }}=0,71\right)$. 
Tablo 6'da her bir maddenin iki formattaki madde güçlük ve madde ayırt edicilik değerleri verilmiştir.

Tablo 6. Orijinal Madde ile Cevaba Yönelten Resim Eklenen Maddelerin Madde Güçlük ve Madde Ayırt Edicilik Değerleri.

\begin{tabular}{|c|c|c|c|c|}
\hline \multirow[b]{2}{*}{$\begin{array}{l}\text { Madde çiftleri } \\
\text { (Madde Nu.) }\end{array}$} & \multicolumn{2}{|c|}{$\begin{array}{c}\text { Orijinal (Resimsiz) } \\
\text { Maddeler }\end{array}$} & \multicolumn{2}{|c|}{$\begin{array}{l}\text { Cevaba Yönelten Resim } \\
\text { Eklenen Maddeler }\end{array}$} \\
\hline & $\begin{array}{l}\text { Madde } \\
\text { Güçlük } \\
\text { Indeksi }\end{array}$ & $\begin{array}{l}\text { Madde Ayırt } \\
\text { Edicilik } \\
\text { Indeksi }\end{array}$ & $\begin{array}{l}\text { Madde } \\
\text { Güçlük } \\
\text { Indeksi }\end{array}$ & $\begin{array}{l}\text { Madde Ayırt } \\
\text { Edicilik } \\
\text { Indeksi }\end{array}$ \\
\hline $1(1)$ & 0,71 & 0,41 & 0,80 & 0,37 \\
\hline $2(3)$ & 0,85 & 0,56 & 0,96 & 0,36 \\
\hline $3(5)$ & 0,72 & 0,60 & 0,96 & 0,25 \\
\hline $4(7)$ & 0,68 & 0,60 & 0,73 & 0,58 \\
\hline $5(9)$ & 0,59 & 0,55 & 0,65 & 0,59 \\
\hline $6(11)$ & 0,26 & 0,32 & 0,32 & 0,25 \\
\hline 7 (13) & 0,66 & 0,58 & 0,66 & 0,59 \\
\hline 8 (15) & 0,51 & 0,52 & 0,69 & 0,49 \\
\hline 9 (17) & 0,85 & 0,49 & 0,91 & 0,50 \\
\hline 10 (19) & 0,61 & 0,52 & 0,58 & 0,53 \\
\hline
\end{tabular}

Yapılan testteki maddelerin Tablo 5 ve Tablo 6'da verilen değerlerinde orijinal formattaki maddelerin hepsinin madde ayırt ediciliğinin yüksek olduğu; testten çıkarılması gereken madde bulunmadığı görülmektedir.

\section{Test Güvenirliği}

Güvenirlik katsayısı, testte yer alan maddelerin testin tamamı ile uyumunu gösterir ve 0 ile 1 arasında değerler alır. Güvenirlik katsayısının 1'e yakın bir değer alması testin maddeleri arasındaki iç tutarlılığın yüksek olduğu ve testin güvenilir sonuçlar ürettiği şeklinde yorumlanır. 1'e yaklaştıkça iç tutarlık anlamındaki güvenirlik katsayısının yüksek olduğu ifade edilir (Baykul, 2000).

$\mathrm{Bu}$ çalışmada, Cronbach Alpha güvenirlik katsayıs1, orijinal formatta 0,70 iken, maddenin köküne eklenen resim formatında 0,78 bulunmuştur.

Cronbach Alpha güvenirlik katsayısı, orijinal soru formatında 0,73 iken maddeye eklenen cevaba yönelten resim formatında 0,67 bulunmuştur. Ölçme sonuçlarının tesadüfi hatalardan arını olma derecesi olarak ifade edilen güvenirliğin, maddeye cevaba yönelten resim eklenince düştüğü görülmüştür. 


\section{SONUÇLAR VE TARTIŞMA}

$\mathrm{Bu}$ çalışma, İngilizce dersi test maddelerinde resim kullanımının test ve madde psikometrik özelliklerine etkisini ölçmek amacıyla hazırlanmıştır. Çalışmada maddeye eklenerek kökünü açıklayan ve de cevaba yönelten resimlerin testin psikometrik özelliklerini olan etkileri araştırılmıştır. Araştırmada madde güçlüğü, madde ayırt ediciliği ve test güvenirliği ögeleri resmin kullanımın amacına göre farklılık gösterdiği sonucuna ulaşılmıştır.

Madde güçlüğü açısından bakıldığında, madde köküne resim eklenen ile orijinal madde grubunun madde güçlük değerlerinde istatistiksel olarak anlamlı bir fark yoktur. Resimsiz haline göre madde köküne eklenen resmin soruyu kolaylaştırmadığ 1 ya da zorlaştırmadığı sonucuna varılmıştır. Cevaba yönelten resim eklenen madde ile orijinal madde grubunun madde güçlük değerleri arasındaki fark istatistiksel olarak anlamlıdır. Cevaba yönelten resim eklenmesi, maddenin orijinal haline göre maddeyi kolaylaştığı görülmektedir.

Madde ayırt ediciliği sonuçlarına bakıldığında, madde kökünde resim olan maddelerin madde ayırt edicilik değerlerinin (medyan değerinin) orijinal madde formatındaki maddelere göre daha yüksek olduğu görülmüştür. Cevaba yönelten resim eklenen madde ile orijinal madde grubunun madde ayırt edicilik değerleri farklılıkların ise istatistiksel olarak anlamlı olmadığı bulunmuştur.

Testlerin güvenirlik katsayısı incelendiğinde maddenin köküne eklenen resim formatında, orijinal haline göre daha yükssek çıkmıştır. Bu durum testin maddeleri arasındaki iç tutarlılığın yüksek olduğu ve bu testin orijinal maddelerden oluşan teste göre daha güvenilir sonuçlar ürettiği söylenebilir. Güvenirlik katsayısı, cevaba yönelten resim eklenmiş madde grubunda, orijinal haline göre daha düşük çıkmıştır. Diğer bir ifadeyle maddeye cevaba yönelten resim eklenmesi, testin güvenirliğini düşürdüğü görülmüsstür.

Sonuç olarak, madde köküne resim eklenmesi madde ayırt ediciliği arttırırken, maddelere cevaba yönelten resim eklenmesi madde ayırt ediciliğini değiştirmemiştir. Köküne resim eklenen maddelerin madde güçlüklerinde anlamlı bir değişim olmazken, cevaba yönelten resim eklenen maddelerin madde güçlükleri azalmıştır. Maddenin köküne eklenen resim, testin güvenirliğini arttırırken; maddeye eklenen cevaba yönelten resim, testin güvenirliğini düşürmüştür.

Hunt (1978) tarafindan yapılan çalışmada, tıp sınav sorularına görsel öğe eklemenin sınav başarısına etkisi ölçülmüş ve gerçek görsel resim eklenen maddelerin madde güçlüğü azalmış ancak madde ayırt edicilik değerlerine istatistiksel olarak anlamlı bir etki yapmadığı sonucuna ulaşılmıştır. Elde edilen sonuç, bu araştırmanın cevaba yönelten resim eklenen madde sonuçlarıyla 
örtüşmektedir. Ancak madde köküne resim eklenen madde sonuçları ile ters düşmektedir. Çünkü resim soruyu kolaylaştırmış madde güçlügü artmış ve bilen ile bilmeyeni ayırt etme gücüne istatistiksel olarak anlamlı bir katk1 sağlamamıştır. Wasylenky ve Tapajna (2001) çalışmalarında olumlu ve olumsuz görselin okuma parçasını hatırlamadaki etkisine ölçmüşlerdir. Parça ile tutarlı yani olumlu görsel eklemenin parçayı hatırlamaya yardımcı olduğu ancak parça ile tutarsız yani olumsuz resim eklenmesi parçanın doğru hatıllanmasını engellediği sonucuna ulaşmışlardır. Bu da yapılan çalışmadaki maddenin köküne ya da cevabına yönelten resim eklenmesinin sonuçlarının birbirinden farklı olduğu ve parçalara ya da sorulara eklenecek görselin seçimindeki dikkat unsuru ile örtüşmektedir. Diğer bir ifadeyle, eklenen görselin amaca hizmet etmesi gerekmektedir. Berends ve Lieshout (2009), aritmetik problem çözümünde resmin etkisini incelemişlerdir. Çalışma resim eklemenin öğrenciyi meşgul ederek soru çözüm süresini uzattığı, bilginin resimle tekrar edilerek faydasız bir etkisinin olduğu sonucuna ulaşmışlardır. Bu çalışmanın sonucu Haladyna vd. (2002), 16. ilkesi ile tutarl1l1k göstermektedir. Vorstenbosch vd. (2013), anatomi dersi yazılı sınavında görsel kullanımının madde güçlüğü ve madde ayırt ediciliği üzerindeki etkisini inceledikleri çalışmalarında sorularda resim kullanımının madde güçlük ve madde ayırt edicilik değerlerini düşürdüğü sonucuna ulaşmışlardır. $\mathrm{Bu}$ çalışmada resim, madde köküne eklendiğinde madde ayırt edicilik değeri düşerken, madde güçlük değerinde anlamlı bir fark yaratmamıştır. Cevaba yönelten resim eklenen maddelerde ise madde güçlük değerleri düşerken madde ayırt edicilik değerlerinde anlamlı bir fark oluşturmamıştır. Araştırmacıların ulaştığı sonuçlar, çalışmamızın sonuçları ile örtüşmektedir.

Yapılan önceki araştırmalarda sorulara resimlerin maddeyi açıklamak amacıyla mı yoksa cevaba yöneltmek amacıyla mı eklendiği belirtilmemiştir. Eklenen resim her zaman istenilen amaca hizmet etmediği çalışmalardan çıkan genel sonuçlar arasındadır. Öğrencilerde zaman kaybına ve kavram karmaşasına yol açabildiği sonuçları bu çalışma ile ulaşılan madde köküne resim eklemenin madde güçlüğüne ve testin güvenirliğine bir katkı yapmadığ pekişmiştir. Ancak bu çalışmada madde köküne eklenen resim formatında madde ayırt ediciliği orijinal formata göre daha yüksek çıkmıştır. Madde ayırt ediciliğin yüksek olması testin güvenirliğin de yüksek olduğu konusunda bilgi verir. $\mathrm{Bu}$ sonuç, madde köküne resim eklenen testin güvenirliğinin orijinal formata göre yüksek olması ile pekişmektedir.

\section{ÖNERILER}

Bu bölümde, araştırmanın bulgularına dayalı olarak elde edilen sonuçlara ve bu sonuçlar doğrultusunda geliştirilen önerilere yer verilmiştir.

Uygulayıcılara yönelik öneriler: 
- Maddelere eklenen görsel materyalin kullanım amacına hizmet etmesine dikkat edilebilir.

- Sinavlarda kullanılan görsel ögelerin maddeye olan etkisi belirlenerek kullanılabilir.

- Çoktan seçmeli testlerde kullanılan maddelere resim eklemenin her zaman olumlu katk1 yapmadığı sonucu göz önünde bulundurulabilir ve etkisine göre görseller eklenebilir.

Araştırmacılara yönelik öneriler:

- $\mathrm{Bu}$ araştırma, İngilizce dersi için yapılmıştır, benzer araştırmalar farklı derslerin soruları üzerinde de yapılabilir.

- Araştırmada maddenin köküne resim eklemek ve cevaba yönelten resim eklemek kategorileri değerlendirilmiştir. Yapılacak farklı çalışmalarda seçeneklerde resim kullanılması kategorisi de eklenebilir.

- $\mathrm{Bu}$ çalışmada farklı maddelere cevaba yönelten ve maddeyi açıklayan resimler eklenmiştir. Benzer araştırmalarda aynı maddelere farklı türde resimler eklenebilir ve etkisi ölçülebilir.

- $\mathrm{Bu}$ çalışmada maddelere resim eklemenin etkisi araştırılmıştır. Yapılacak farklı çalışmalarda grafik veya tablo eklemenin madde üzerindeki istatistiksel etkileri araştırılabilir.

- Araştırmada öğrenciler seviye gruplarına ayrılmadan rastgele olarak dağıtılan kitapçıklardaki soruları çözmüşlerdir. Benzer araştırmalar öğrenciler seviye gruplarına ayrılarak yapılabilir. Böylece seviye grupları üzerinde resmin etkisi araştırılabilir.

- $\mathrm{Bu}$ çalışmada öğrencilere toplam 40 dakika süre verilmiştir, başka çalışmalarda farklı gruplarda öğrencilerin testi çözme hızları kaydedilip, resmin test çözme hızı üzerindeki etkisi araştırılabilir.

- Benzer araştırmalarda maddelerin sonuna, öğrencilerin resim eklenmesi hakkındaki görüşlerini almak için nitel bir ölçek eklenip çalışma desteklenebilir.

- Bu çalışmada soru sayısı 10 olduğu için analiz yapılırken parametrik olmayan ilişki testi kullanılmıştır. İleriki çalışmalarda soru sayısı arttırılıp parametrik testler kullanılabilir. 


\section{KAYNAKLAR}

Atılgan, Hakan; Kan, Adnan ve Doğan, Nuri (2009), Eğitimde Ölçme ve Değerlendirme. Anı Yayıncılık, Ankara.

Atılgan, Hakan; Kan, Adnan ve Doğan, Nuri (2007), Eğitimde Ölçme ve Değerlendirme, Anı Yayıncılık, Ankara.

Baykul, Yaşar (2000), "Egitimde ve Psikolojide Ölçme: Klasik Test Teorisi ve Uygulaması [Measurement in Education and Psychology: Classical Test Theory and Application].", ÖSYM Yayınları, Ankara.

Berends, Inez E.; Ernest, CDM ve Lieshout Van (2000), "The Effect of Illustrations in Arithmetic Problem-Solving: Effects of Increased Cognitive Load." Learning and Instruction 19/4, ss.345-353.

Büyüköztürk, Şener (2016), Sosyal Bilimler için Veri Analizi El Kitabı, Pegem Akademi Yayıncılık, Ankara.

Büyüköztürk, Şener; Çokluk, Ömay ve Köklü Nilgün (2015), Sosyal Bilimler için İstatistik, Pegem Akademi Yayıncılık, Ankara.

Collins, Jannette (2006), "Education Techniques for Lifelong Learning: Writing Multiple-Choice Questions for Continuing Medical Education Activities and Self-Assessment Modules." Radiographics: a review publication of the Radiological Society of North America, Inc 26.2, ss.543-551.

Crocker, Linda ve James Algina (1986), Introduction to Classical and Modern Test Theory. Holt, Rinehart and Winston, 6277 Sea Harbor Drive, Orlando, FL 32887.

Doğan, Nuri ve A. ATA Tezbaşaran (2003), "Klasik Test Kuramı ve Örtük Özellikler Kuramının Örneklemler Bağlamında Karşılaştırılması." Hacettepe Üniversitesi Eğitim Fakültesi Dergisi 25.25.

Güler, Neşe (2017), "Eğitimde Ölçme ve Değerlendirme." Pegem Atıf İndeksi, ss.1-196.

Haladyna, Thomas M.- Steven M. Downing- Michael C. Rodriguez (2002), "A Review of Multiple-Choice Item-Writing Guidelines for Classroom Assessment." Applied measurement in education, 15/3, ss.309-333. 
Hunt, David. R. (1978), “Illustrated Multiple Choice Examinations”, Medical Education, 12(6), ss. 417-420.

Karasar, Niyazi (2012), Bilimsel Araştırma Yöntemi, 23. Basım. Nobel Akademik Yayıncılık, Ankara.

McCoubrie, Paul (2004), "Improving the Fairness of Multiple-Choice Questions: A Literature Review”, Medical Teacher, 26(8), ss.709-712.

MEB (Millî Eğitim Bakanlığı) (2011), “Ortaöğretim Kurumları İngilizce Dersi Öğretim Programı” (Talim Terbiye Kurulu Başkanlığı).

MEB (Millî Eğitim Bakanlığı) (2015), Temel Eğitimden Ortaöğretime Geçiş Ortak Sınav Başarısının Çeşitli Değişkenler Açısından İncelenmesi, http://odsgm.meb.gov.tr/test/analizler/docs/Ortak-Sinavlar-ArastirmaRaporu.pdf (25.12.2019).

MEB (Millî Eğitim Bakanlığı) (2016), 2015-2016 Eğitim Öğretim Yılı II. Dönem Ortak Sınav Test ve Madde İstatistikleri, http://odsgm.meb.gov.tr/test/analizler/docs/2015-2016-ortak-sinav-2donem-madde-istatistikleri.pdf (25.12.2019).

MEB (Millı̂ Eğitim Bakanlığı) (2017), 2016-2017 Eğitim Öğretim Yılı II. Dönem Ortak Sinav Test ve Madde İstatistikleri, http://odsgm.meb.gov.tr/test/analizler/docs/2016-2015-ortak-sinav-2donem-madde-istatistikleri.pdf (25.12.2019).

Notebaert, Andrew. J. (2017), “The Effect of Images on Item Statistics in Multiple Choice Anatomy Examinations”, Anatomical Sciences Education (DOI 10.1002/ase.1637) University of Mississippi Medical Center, Mississippi, ss. 68-78.

Ollerenshaw, Alison; Eugene Aidman ve Garry Kidd (1997), "Is an Illustration Always Worth Ten Thousand Words? Effects of Prior Knowledge, Learning Style and Multimedia Illustrations on Text Comprehension”, International Journal of Instructional Media, 24(3), ss. 227-239.

Osterlind, Steven J. (1989), "Judging the Quality of Test İtems: Item Analysis”, In Constructing Test Items, Springer, Dordrecht, ss. 259-310.

Özcan, Kürşat Volkan: İdris Göksu ve Selçuk Karaman (2014), “Çoktan Seçmeli Testlerin Dekoratif Resimlerle Desteklenmesinin Testin Puanına ve Tamamlanma Süresine Etkisi”, Gaziosmanpaşa Bilimsel Araştırma Dergisi, 9(2014), ss.13-19. 
Turgut, M. Fuat ve Baykul, Yaşar (2012), Eğitimde Ölçme ve Değerlendirme, Pegem Akademi, Ankara.

Turgut, M. Fua. ve Baykul, Yaşar (1987), Eğitimde Ölçme ve Değerlendirme Metotları, Yargıcı Matbaası, Ankara.

Vorstenbosch, Marc. A.; Klaassen, Tim P.; Kooloos, Jan. G.; Bolhuis, Sanneke. M. ve Laan, Roland, F. (2013). "Do Images Influence Assessment in Anatomy? Exploring the Effect of Images on Item Difficulty and Item Discrimination”, Anatomical Sciences Education, 6 (1), ss. 29-41.

Wasylenky, Krista ve Tapajna, Nicole (2001), “The Effects of Positive and Negative Illustrations on Text Recall”, Cahiers Linguistiques D Ottawa (2001), ss. 105-112. 